\title{
Agronomic performance and genotypic diversity for morphological traits among early maize genotypes
}

\author{
Bhim Nath Adhikari ${ }^{1}$, Jiban Shrestha ${ }^{2}$, Bishal Dhakal ${ }^{1}$, Bishnu Prasad Joshi ${ }^{1}$, \\ \& Naba Raj Bhatta ${ }^{1}$ \\ ${ }^{1}$ Regional Agriculture Research Station (RARS), Dipal, Doti, NARC, Nepal \\ ${ }^{2}$ National Commercial Agriculture Research Program, Pakhribas, Dhankuta, Nepal
}

\begin{abstract}
Detailed information on the genetic diversity between maize germplasm (Zea mays L.) is useful for their systematic and efficient use in breeding programs. Fourteen early maize genotypes were studied to assess their performance and genotypic diversity at Doti, Nepal in 2015. Days to tasseling, days to silking, plant height, ear height, ear length, ear diameter and grain yield were significant among genotypes. Genotype SO3TEY-POBM, COMPOL-NIOBP and ACROSS-99402 were found higher yielder with earlier maturity. Days to tasseling (0.85), days to silking (0.82), plant height (0.79), ear length (0.71) and ear diameter (0.66) were found highly heritable traits. Grain yield (0.39) and ear height $(0.47)$ medium and remaining traits showed low heritability. High PCV was observed for grain yield $(35.10 \%)$, number of plants/plot (34.46\%), tesseling silking interval (26.85\%), harvested ears/plot (24.45\%) and husk cover rating (22.85\%) where other traits showed medium to low PCV. Grain yield showed high GCV $(21.96 \%)$, ear height and husk cover had medium and remaining traits showed low GCV ( $<10 \%)$. Plant height $(r=0.498)$, harvested plants/plot $(r=0.412)$, harvested ear/plot $(r=0.762)$, ear length $(r=0.472)$ and ear diameter $(r=0.470)$ showed significant positive correlation with grain yield. The yield can be improved if selection applied in favor of those yield components.
\end{abstract}

\section{Article History}

Received 30 October 2018

Accepted 25 December 2018

\section{Keyword}

Maize

Variability

Heritability

Genetic advance

Correlation

\section{Introduction}

Maize (Zea mays L.) is second important crop after rice in Nepal. It is cultivated in 891583 ha with $2503 \mathrm{~kg} / \mathrm{ha}$ national productivity (MOAD, 2017). The majority of the maize area lies in the mid hills across the country where it is the first principal staple food and feed crop and produce about $70 \%$ of national maize production. Therefore maize can be considered as source of livelihood for hilly farmers. It is a traditional crop cultivated on slopping upland terraces (bariland) in the hills under rainfed condition during the summer on which fingermillet is relayed in majority, however sole maize was dominantly followed by wheat. Hilly areas of western Nepal is mostly food deficit, drought prone areas where annual 
average rainfall is about $1000 \mathrm{~mm}$ and rainfall distribution is erratic and unpredictable. Lower productivity of maize is associated with lack of suitable varieties for stress environments, inadequate variety in the existing system, lack of agricultural inputs like irrigation, fertilizers etc. Early maturing maize will also ensure for timely wheat sowing in maize-wheat system which may lead proper germination and initial growth of wheat because wheat is grown on residual moisture and if sown late germination and growth may be adversely affected due to lack of moisture in bariland farming. In addition early maturing maize also compete less with fingermillet for sunlight, nutrients and moisture than full season maize in maize/millet relay cropping with ultimately support to increase fingermillet yield. Thus improved maize genotypes with early maturity and high yield, tolerant to drought and better fit into existing system will increase and stabilize yield of maize, fingermillet and wheat on bariland farming system of hilly areas.

Variability is the differences between individuals in a population due to genetic composition and growing environment (Sumanth et al., 2017). The existence of variability is utmost role as success of any plant breeding program depends on the genetic variability and selection skill of plant breeder (Adhikari et al., 2018). Selection is only effective if the parent population have significant amount of variability. Phenotypic coefficient of variation (PCV) and genotypic coefficient of variation (GCV) provides insight information on magnitude of variability in a population and heritability shows the component of a character transmitted to future generations (Pal et al., 2016; Girma et al., 2018) Further, heritability coupled with genetic advance shows the expected genetic gain in next generation (Shukla et al., 2006). In addition, correlation between yield and yield attributing traits are prime important for indirect selection for those traits which have high heritability and closely associated to contributes to improve yield (Aditya \& Bhartiya, 2013). Therefore, the study was under taken to identify suitable early maturing genotypes and to know the information on variability, heritability, genetic advance and traits correlation on tested materials to utilize it on future maize breeding activity which aim to develop suitable genotype for rainfed bariland farming of mid hills areas of Nepal.

\section{Materials and Methods}

\section{Experimental Location}

The experiment was conducted at Regional Agricultural Research Station, Dipayal, Doti. Geographically, it is situated at $80^{\circ} 55^{\prime}$ east longitude and $29^{\circ} 15^{\prime}$ north latitude and the altitude of this station is 510 masl (RARS, 2015). The climate is sub tropical, generally monsoon starts late in July and it is erratic with average annual rainfall of about $900 \mathrm{~mm}$. Experimental field soil was shallow in depth and porous, sandy loam, slightly acidic with $\mathrm{pH}$ 5.5-6.0, low in nitrogen and organic matter i.e. 1-2\% and $0.6 \%$ respectively and the water holding capacity of the soil is very low (RARS, 2015).

\section{Genotypes}

The experiment was carried out with fourteen different early maize genotypes in which 13 were received from National Maize Research Program (NMRP), Rampur and Farmer's variety was collected from Dipayal, Doti. The tested genotype were: Earlymid Katamani, Rajahar Local, S97TEYGHAYB(3), POP-445/POP-446, COMPOL-NIBP, RC/POOL-17, SO3TEY/LM, Arun-4 (standard check variety), Farmer's variety (local check variety), ZM621/POOL-15, EEYC1, SO3TEY-LN/PP, SO3TEY-PO-BM and Across-99402. 


\section{Experimental Design and cultural practices}

The experiment was planted on $2^{\text {nd }}$ week of June in Randomized Complete Block Design (RCBD) with three replications. Along with FYM @ $10 \mathrm{t} /$ ha chemical fertilizers at the rate of 60:60:40 N P2 $\mathrm{O}_{5} \mathrm{~K}_{2} \mathrm{O} \mathrm{kg} / \mathrm{ha}$ in the form of Urea, DAP and Murate of Potash were applied during final land preparation. Top dressing was done by $60 \mathrm{~kg} \mathrm{~N} / \mathrm{ha}$ in two splits, i.e. $30 \mathrm{~kg}$ $\mathrm{N} / \mathrm{ha}$ at knee high stage and $30 \mathrm{~kg} \mathrm{~N} / \mathrm{ha}$ at just before tasseling stage. Individual plot size was $3 \mathrm{~m} \times 3 \mathrm{~m}$ (4 rows of $3 \mathrm{~m}$ long). Seed was shown @ 2 seeds/hills in $75 \mathrm{~cm}$ apart rows by maintaining $25 \mathrm{~cm}$ between hill to hill in a row. Thinning was done to maintain plant population after 3 weeks of germination. Intercultural operations were done as per recommendation of National Maize Research Program.

\section{Data measurement}

Days to tasseling, days to silking, number of plants harvested, number of cob harvested, field weight were taken from central 2 rows from each plot. Five plants form central rows randomly selected and plant height, ear height, ear length, ear diameter recorded and mean values was taken for analysis. Husk cover rating was taken as 1-5 scale where 1 is good and 5 is poor. After taking field weight, composite grains from five randomly selected ears prepared and moisture reading taken for thrice and mean was used for yield estimation. Grain yield was estimated at $15 \%$ moisture and $80 \%$ shelling coefficient by below formula which was also adopted by Carangal et al. (1971) and Shrestha et al. (2018).

$$
\text { Grain yield }\left(\frac{\mathrm{kg}}{\mathrm{ha}}\right)=\frac{\mathrm{F} . \mathrm{W} \cdot\left(\frac{\mathrm{kg}}{\mathrm{plot}}\right) \times(100-\mathrm{HMP}) \times \mathrm{S} \times 10000}{(100-\mathrm{DMP}) \times \mathrm{NPA}}
$$

Where,

F.W. = Fresh weight of ear in kg per plot at harvest

$\mathrm{HMP}=$ Grain moisture percentage at harvest

DMP = Desired moisture percentage, i.e. $15 \%$

$\mathrm{NPA}=$ Net harvest plot area, $\mathrm{m}^{2}$

$S=$ Shelling coefficient, i.e. 0.8

\section{Data analysis}

Analysis of variance and correlation among traits were done by using Genstat $18^{\text {th }}$ edition at 0.05 level of significance. Likewise significance of correlation coefficient was done as proposed by Kothari (2004). The phenotypic and genotypic variances were computed according to Falconer (1981). Broad sense heritability was calculated using formula suggested by Allard (1960) and categorized as low (0-0.3), moderate (0.30-0.6) and high (>0.6). The estimates of genetic advance were obtained at $5 \%$ selection intensity and categorized as high $(>20 \%)$, medium $(10-20 \%)$ and low $(<10 \%)$ as suggested by Johnson et al. (1955). Coefficient of genotypic and phenotypic variation were also categorized as high (>20\%), medium (10$20 \%$ ) and low ( $<10 \%)$ as proposed by Sivasubramanian and Madhavamenon (1973). 


\section{Results and Discussion}

\section{Analysis of Variance}

The analysis of variance for 10 quantitative characters showed significant differences among the evaluated genotypes for days to tasseling, days to silking, plant height, ear height, ear length, ear diameter and grain yield. However, differences were not significant for tasseling silking interval days, number of harvested plants/plot, number of harvested cobs/plot and husk cover rating (Table 1 and 2). Statistical traits indicated the existence of inherent genetic variation among tested genotypes for those traits. Thus there is scope to enhance genetic yield potential through selection and hybridization. Existence of significant genetic variability among maize genotypes for yield and major yield attributing traits were reported by Vashistha et al. (2013), Ogunniyan and Olakojo (2014), Pahadi and Sapkota (2016), Bhusal et al. (2017), Kandel et al. (2018) and Sharma et al., (2018). Prasai et al. (2015) also reported genetic variability on early maize. Similarly, Shrestha (2014) observed morphological variation in maize inbred lines in Chitwan, Nepal.

\section{Agronomic performance}

Agronomic performance observed on yield and yield attributing characters were summarized and presented in Table 1 and 2.

\section{Days to tasseling, silking and tasseling silking interval}

Genotypic differences were observed significant for both days to silking and tasseling but the interval between silking and tasseling remained statistically non-significant. The silking tasseling intervals remained 2-3 days for all tested genotypes. Farmers variety observed earliest in tasseling and silking took 37 and 40 days respectively which was followed by S97TEYGHAYB(3) and Arun-4 both took 45 and 48 days respectively for tasseling and silking. Genotype SO3TEY/LM observed late took 51 days for tasseling and 53 days for silking. This observation clearly indicated that farmer's variety is extra early and could be one of the parents for maize hybridization program to develop early maturing variety. Significant difference among tested maize genotypes for days to tasseling and silking were previously reported by (Vashistha et al., 2013; Prasai et al., 2015; Sharma et al., 2018; Bhusal et al., 2017).

\section{Plant and ear height}

Significant differences for plant and ear height observed indicated the existence of genetic variability among genotypes kept under study. Rajahar Local was the tallest genotype in plant height $(287 \mathrm{~cm})$ and ear height $(126 \mathrm{~cm})$ whereas farmers' variety was observed as dwarf genotypes. Standard check variety (Arun-4) and ZM621/POOL-15 were found medium in plant and ear height. In favor of present study, genotypic variation on plant and ear height were previously reported by (Ogunniyan and Olakojo, 2014; Parsai et al., 2015; Sharma et al., 2018).

\section{Plant and ear harvested}

Tested genotypes were not differed statistically for number of plants and ear harvested per unit area. Mean harvested plants and ear were found 14 and 16 respectively. Similar result on harvested plant and ears on early maturing maize were reported by Katuwal et al. (2017). 


\section{Ear length, diameter and Husk cover rating}

Genotypic differences were observed for ear length and diameter but rating based on husk cover remained at par between genotypes. Across-99402 was observed highest ear length and farmer's variety was shortest ear length. Likewise, genotype ZM 621/POOL-15 was found having highest ear diameter while farmer's variety was lowest. Husk cover rating was observed 2-3 for all genotypes. Genetic difference on ear length and diameter were also reported by (Vashistha et al., 2013; Pahadi \& Sapkota, 2016).

\section{Grain Yield}

The grain yield was found statistically significant indicating the existence of genetic variability on yield potential on the tested genotypes. Higher yielder genotypes observed were SO3TEY-PO-BM, COMPOL-NIOBP, ACROSS-99402 could be selected as promising genotypes for early maturing groups or may be used as a parent in maize breeding program to develop early maturing maize varieties. Likewise, farmer's variety was poor yielder but due to its early maturing character it can also be used as a parent for the purpose. Genetic variability on maize genotypes was reported by many authors including (Vashistha et al., 2013; Bhusal et al., 2017; Katuwal et al., 2017).

\section{Genetic parameter estimation}

Estimated genetic parameter such as the phenotypic coefficient of variation (PCV), the genotypic coefficient of variation (GCV), broad sense heritability, and genetic advance as percent of means are presented in Table 3. Yield and yield attributing traits under study showed higher phenotypic coefficient of variance than genotypic coefficient of variance indicated high environmental influence on the expression of these trait, however, as compared with others, less environmental influence was observed for days to silking, tasseling and plant height. Similar results were presented by (Pahadi and Sapkota, 2017; Bisen et al., 2018; Sharma et al., 2018). High PCV was observed for grain yield, number of plants/plot, tesseling silking interval, harvested ears/plot and husk cover rating where as remaining traits showed medium to low PCV. Similarly high GCV was estimated for grain yield, medium for ear height and husk cover rating and remaining traits showed low GCV. In line with this findings high PCV and GCV for grain yield was also reported by (Ogunniyan and Olakayo, 2014; Bhusal et al., 2017; Bisen et al., 2018; Sharma et al., 2018).

Table 1. Mean performance of yield attributing traits on maize

\begin{tabular}{cllllll}
\hline SN & \multicolumn{1}{c}{ Genotype } & DT & DS & TSI & PH & EH \\
\hline 1 & Early Mid Katamani & $50^{\mathrm{fg}}$ & $52^{\text {def }}$ & 2.33 & $250^{\text {def }}$ & $100^{\text {abcd }}$ \\
2 & Rajahar Local Variety & $48^{\text {bcdf }}$ & $50^{\text {bcde }}$ & 2.67 & $287^{g}$ & $126^{\text {d }}$ \\
3 & S97TEYGHAYB(3) & $45^{\mathrm{b}}$ & $48^{\mathrm{b}}$ & 3.00 & $211^{\mathrm{ab}}$ & $75^{\mathrm{a}}$ \\
4 & POP-445/POP-446 & $46^{\mathrm{bcde}}$ & $49^{\mathrm{bcd}}$ & 3.67 & $222^{\mathrm{bc}}$ & $78^{\mathrm{ab}}$ \\
5 & COMPOL-NIBP & $50^{\mathrm{fg}}$ & $53^{\text {ef }}$ & 3.00 & $232^{\mathrm{bcd}}$ & $77^{\mathrm{ab}}$ \\
6 & RC/POOL-17 & $47^{\mathrm{bcdef}}$ & $50^{\mathrm{bcd}}$ & 2.33 & $251^{\text {def }}$ & $111^{\mathrm{cd}}$ \\
7 & SO3TEY/LM & $51^{\mathrm{g}}$ & $53^{\mathrm{f}}$ & 2.33 & $256^{\text {ef }}$ & $107^{\mathrm{cd}}$ \\
8 & Arun-4 & $45^{\mathrm{bc}}$ & $48^{\mathrm{bc}}$ & 3.00 & $245^{\mathrm{cde}}$ & $106^{\mathrm{cd}}$ \\
9 & Farmer's Variety & $37^{\mathrm{a}}$ & $40^{\mathrm{a}}$ & 2.67 & $195^{\mathrm{a}}$ & $75^{\mathrm{a}}$ \\
10 & ZM621/POOL-15 & $48^{\text {cef }}$ & $51^{\text {cdef }}$ & 3.00 & $241^{\text {cde }}$ & $97^{\mathrm{abc}}$ \\
11 & EEYC1 & $45^{\mathrm{bcd}}$ & $48^{\mathrm{b}}$ & 2.67 & $271^{\mathrm{fg}}$ & $101^{\mathrm{abcd}}$ \\
12 & SO3TEY-LN/PP & $49^{\mathrm{fg}}$ & $52^{\text {def }}$ & 2.33 & $253^{\text {def }}$ & $96^{\mathrm{abc}}$
\end{tabular}




\begin{tabular}{lllllll}
\hline 13 & SO3TEY-PO-BM & $49^{\mathrm{fg}}$ & $52^{\text {def }}$ & 3.00 & $273^{\mathrm{fg}}$ & $102^{\mathrm{bcd}}$ \\
14 & ACROSS-99402 & $49^{\mathrm{fg}}$ & $51^{\text {def }}$ & 2.33 & $233^{\mathrm{bcd}}$ & $90^{\mathrm{abc}}$ \\
\hline Mean & 47 & 50 & 2.74 & 244 & 96 \\
SEM & 1.17 & 1.24 & 0.57 & 9.97 & 11.14 \\
P value & $<.001$ & $<.001$ & 0.534 & $<.001$ & 0.002 \\
CV\% & 3.0 & 3.1 & 25.9 & 5.0 & 14.2 \\
LSD (0.05) & 2.4 & 2.56 & & 20.48 & 22.9 \\
\hline
\end{tabular}

Means followed by a superscripted common letter with in a column are not significantly different from each other at $P \leq 0.05$. $D T=$ Days to tasseling, DS= Days to silking, $T S I=$ Tasseling silking interval, $P H=$ Plant height $(\mathrm{cm}), E H=$ Ear height $(\mathrm{cm})$

Due to the lower differences estimated between PCV and GCV selection based on phenotypic performance for days to tasseling, silking and plant height would be effective to bring about considerable genetic improvement on the tested maize population for these traits but agronomic performance can't improve by providing favorable environment without selection. Traits showing higher difference between GCV and PCV indicated that these traits are more influenced by growing environment thus selection is not effective on those traits, can be maintained by providing optimum growing environment.

Table 2. Mean performance of grain yield and yield attributing traits on maize

\begin{tabular}{|c|c|c|c|c|c|c|c|}
\hline SN & Genotypes & $\mathrm{P} / \mathrm{P}$ & $E / P$ & EL & ED & $\mathrm{HC}$ & GY \\
\hline 1 & Early Mid Katamani & 14 & 16 & $14.00^{\mathrm{bc}}$ & $4.20^{\mathrm{bc}}$ & 3.00 & $2945^{\mathrm{abcd}}$ \\
\hline 2 & Rajahar Local Variety & 18 & 17 & $13.33^{b}$ & $4.17^{b}$ & 2.67 & $3013^{\mathrm{abcd}}$ \\
\hline 3 & S97TEYGHAYB(3) & 19 & 17 & $14.33^{\mathrm{bcd}}$ & $4.37^{\text {bcde }}$ & 2.67 & $3109^{b c d}$ \\
\hline 4 & POP-445/РOP-446 & 11 & 13 & $14.00^{b c}$ & $4.40^{\text {bcde }}$ & 2.67 & $2225^{a b}$ \\
\hline 5 & COMPOL-NIBP & 14 & 18 & $14.67^{\mathrm{bcd}}$ & $4.60^{\mathrm{ef}}$ & 2.33 & $4179^{d}$ \\
\hline 6 & RC/POOL-17 & 15 & 15 & $13.67^{b}$ & $4.40^{\text {bcde }}$ & 3.00 & $2299^{a b}$ \\
\hline 7 & SO3TEY/LM & 9 & 17 & $14.67^{\mathrm{bcd}}$ & $4.53^{\text {ef }}$ & 3.00 & $3409^{b c d}$ \\
\hline 8 & Arun-4 & 15 & 14 & $14.00^{b c}$ & $4.20^{\mathrm{bcd}}$ & 2.67 & $2834^{\mathrm{abcd}}$ \\
\hline 9 & Farmer's Variety & 10 & 11 & $10.00^{\mathrm{a}}$ & $3.87^{a}$ & 2.00 & $1409^{a}$ \\
\hline 10 & ZM621/POOL-15 & 14 & 11 & $14.33^{\mathrm{bcd}}$ & $4.77^{f}$ & 2.33 & $2392^{\mathrm{abc}}$ \\
\hline 11 & EEYC1 & 18 & 18 & $14.33^{\mathrm{bcd}}$ & $4.50^{\text {cef }}$ & 2.00 & $3880^{\mathrm{bcd}}$ \\
\hline 12 & SO3TEY-LN/PP & 14 & 18 & $14.00^{\mathrm{bc}}$ & $4.37^{\text {bcde }}$ & 2.00 & $3522^{\mathrm{bcd}}$ \\
\hline 13 & SOЗTEY-PO-BM & 14 & 17 & $15.33^{\mathrm{cd}}$ & $4.60^{\text {ef }}$ & 2.00 & $4333^{d}$ \\
\hline \multirow[t]{6}{*}{14} & ACROSS-99402 & 18 & 18 & $15.67^{d}$ & $4.63^{\text {ef }}$ & 2.33 & $3976^{\mathrm{cd}}$ \\
\hline & Mean & 14 & 16 & 14.02 & 4.40 & 2.48 & 3108.93 \\
\hline & SEM & 3.91 & 2.97 & 0.64 & 0.13 & 0.41 & 695.1 \\
\hline & $P$ value & 0.314 & 0.273 & $<.001$ & $<0.001$ & 0.108 & 0.01 \\
\hline & $\mathrm{CV} \%$ & 33.2 & 23.3 & 5.6 & 3.6 & 20.4 & 27.4 \\
\hline & LSD (0.05) & & & 1.32 & 0.26 & & 1428.8 \\
\hline
\end{tabular}

Means followed by a superscripted common letter with in a column are not significantly different from each other at $P \leq 0.05$. $P / P=$ Number of harvested plants $/$ plot, $E / P=$ Number of harvested ears $/$ plot, EL=Ear length $(\mathrm{cm}), E D=$ Ear diameter $(\mathrm{cm})$ $H C=$ Husk cover rating in 1-5 scale, $G Y=$ Grain Yield $\mathrm{kg} / \mathrm{ha}$

Among the studied traits broad sense heritability ranged from 0.04 (TSI) to 0.85 days to tasseling. Heritability is grouped as low $(<0.3)$, moderate $(0.3-0.6)$ and high $(>0.6)$. Based on this category days to tasseling, days to silking, plant height, ear length and ear diameter were found highly heritable traits. Grain yield and ear height medium and remaining traits showed low heritability. High heritability for days to tasseling, days to silking, plant height, 
ear length and ear diameter and high to medium for grain yield were also reported by (Vasistha et al., 2013; Bhusal et al., 2017; Sharma et al., 2018). Medium heritability for grain yield may be due to the influence of the environment on the yield as it is polygenic trait. Low heritability estimates might be due to the variation of environmental component involved for those traits and vice versa. High heritability estimated traits indicated a high response to selection for particular traits.

Estimated heritability is not very much useful because it includes the effect of both additive and non additive gene. The genetic advance with heritability is therefore a useful indicator to achieve expected result on the trait of interest of a population after selection. Further, genetic advance in percentage of mean give more precise result in comparison to only genetic advance. Genetic advance as percent mean was categorized as low $(0-10 \%)$, moderate (10-20\%) and high ( $\geq 20 \%)$. In the present study high genetic advance as percent of mean was estimated for grain yield. Days to tasseling, days to silking, plant height, ear height and ear length showed medium and remaining traits showed low genetic advance as percent of mean. In conformity to this findings, high genetic advance for grain yield and medium to low for other traits also reported by (Vasistha et al., 2013; Ogunniyan and Olakayo, 2014; Sharma et al., 2018). High to medium heritability coupled with medium to low genetic gain indicate observed characters among tested genotypes governed by non-additive gene action and thus heterosis breeding, family selection and progeny testing methods is used for improvement on such traits.

Table 3. Phenotypic (Vp) and genotypic variance (Vg), phenotypic coefficient (PCV) and genotypic coefficient of variance (GCV), heritability (broad sense), genetic advance (GA) and genetic advance as percent of mean (GAM) for observed traits

\begin{tabular}{ccccccccccc}
\hline SN & Traits & Treatment & Error & $\mathbf{V g}$ & $\mathbf{V p}$ & Hbs & GCV & PCV & GA & GAM \\
\hline 1 & DT & 36.26 & 2.06 & 11.40 & 13.46 & 0.85 & 7.17 & 7.79 & 6.40 & 13.60 \\
2 & DS & 34.65 & 2.33 & 10.77 & 13.11 & 0.82 & 6.59 & 7.27 & 5.28 & 10.60 \\
3 & TSI & 0.57 & 0.50 & 0.02 & 0.53 & 0.04 & 5.52 & 26.85 & 0.05 & 2.01 \\
4 & PH & 1830.05 & 148.96 & 560.36 & 709.32 & 0.79 & 9.69 & 10.90 & 37.35 & 15.29 \\
5 & EH & 690.50 & 186.18 & 168.11 & 354.29 & 0.47 & 13.53 & 19.65 & 15.85 & 16.55 \\
6 & P/P & 28.34 & 23.01 & 1.77 & 24.79 & 0.07 & 9.22 & 34.46 & 0.63 & 4.38 \\
7 & E/P & 17.31 & 13.28 & 1.34 & 14.62 & 0.09 & 7.41 & 24.45 & 0.62 & 3.98 \\
10 & EL & 5.15 & 0.62 & 1.51 & 2.13 & 0.71 & 8.76 & 10.42 & 1.83 & 13.08 \\
11 & ED & 0.17 & 0.02 & 0.05 & 0.07 & 0.66 & 4.92 & 6.08 & 0.31 & 7.08 \\
12 & HC & 0.45 & 0.25 & 0.06 & 0.32 & 0.20 & 10.23 & 22.85 & 0.20 & 8.13 \\
15 & GY & 2123268 & 724770 & 466166 & 1190936 & 0.39 & 21.96 & 35.10 & 758.22 & 24.39 \\
\hline
\end{tabular}

$D T=$ Days to tasseling, $D S=$ Days to silking, $T S I=$ Tasseling silking interval, $P H=$ Plant height $(\mathrm{cm}), E H=E a r$ height $(\mathrm{cm}), P / P=$ Number of harvested plants/plot, $E / P=$ Number of harvested ears $/$ plot, $E L=$ Ear length $(\mathrm{cm}), E D=$ Ear diameter $(\mathrm{cm}), H C=H u s k$ cover rating in 1-5 scale, GY= Grain Yield $\mathrm{kg} / \mathrm{ha}, V g=$ genotypic variance, Vp=phenotypic variance, Hbs= Heritability broad sense, $G C V=$ Genotypic coefficient of variation, $P C V=$ Phenotypic coefficient of variation, $G A=$ Genetic advance, GAM= Genetic advance as percent of mean.

\section{Correlation study}

Days to tasseling and silking sowed significant positive correlation. These traits both showed significant positive association plant height, ear length and ear diameter indicated that plant height, ear length and ear diameter can be simultaneously increase while selecting relatively late plants. In line with this findings (Ogunniyan and Olakaago, 2014; Bhusal et al., 2017) reported significant positive correlation between days to tasseling, silking and plant 
height. Further, in conformity to present study (Pahadi and Sapkota, 2016; Khan et al., 2018) also reported significant positive correlation for days to silking with ear length and diameter, however Khan et al. (2018) reported non-significant positive relationship between days to tasseling with ear length and diameter. Similarly, significant positive relationship with days to siliking and non significant positive with days to tasseling towards ear length and ear diamenter was also reported by Sharma et al. (2018). Further plant height have shown significant positive correlation with ear height indicated that ear height can be altered simultaneously while selecting plants on the basis of height. In addition, plant height has shown significant positive association with number of ear harvested showed that ear prolificacy is higher in tall plants. Very similar findings on relationship between plant height, ear height and number of harvested plants were also reoprted by (Ogunniyan and Olakaago, 2014; Bhusal et al., 2017; Sharma et al., 2018). Harvested plants/plot showed significant association with harvested ear/plot. Likewise number of harvested ear showed significant positive association with ear length and ear diameter. Significant positive relation was also observed between ear length and ear diameter. These findings were also partially supported by (Pahadi and Sapkota, 2016; Bhusal et al., 2017; Sharma et al., 2018).

In the present study non significant positive correlation observed between plant height and ear length $(r=0.304)$, plant height and ear diameter $(r=0.285)$, plant height and number of plants/plot $\left(r_{=}=0.267\right)$. Similarly ear height showed non significant positive correlation with plants/plot $(r=0.227)$ and husk cover rating $\left(r_{=}=0.22\right)$. Further both silking and tasseling days shown non significant positive association with husk cover rating and number of ears/plot. Number of harvested pods/plant showed non significant positive correlation with ear length $(r=0.285)$ and ear diameter $(r=0.304)$. On the other side, non significant negative correlation observed between husk cover and ear diameter, husk cover and number of harvested ear/plot, husk cover and number of harvest plants/plot and both days to tasseling and silking with harvested plants/plot.

Table 4. Phenotypic correlation coefficient of grain yield and yield attributing traits on early maize genotypes.

\begin{tabular}{cccccccccc}
\hline Traits & DT & DS & PH & EH & P/P & E/P & HC & EL & ED \\
\hline DT & 1 & & & & & & & & \\
DS & $0.981^{* *}$ & 1 & & & & & & & \\
PH & $0.355^{*}$ & $0.351^{*}$ & 1 & & & & & & \\
EH & 0.162 & 0.165 & $0.733^{* *}$ & 1 & & & & & \\
P/P & -0.078 & -0.038 & 0.267 & 0.227 & 1 & & & & \\
E/P & 0.282 & 0.257 & $0.378^{*}$ & 0.146 & $0.587^{* *}$ & 1 & & & \\
HC & 0.225 & 0.219 & 0.018 & 0.220 & -0.108 & -0.147 & 1 & & \\
EL & $0.701^{* *}$ & $0.718^{* *}$ & 0.304 & 0.071 & 0.285 & $0.360^{*}$ & 0.108 & 1 & 1 \\
ED & $0.467^{* *}$ & $0.492^{* *}$ & 0.285 & 0.037 & 0.304 & $0.316^{*}$ & -0.150 & $0.684^{* *}$ & 1 \\
GY & 0.300 & 0.274 & $0.498^{* *}$ & 0.158 & $0.412^{* *}$ & $0.762^{* *}$ & -0.264 & $0.472^{* *}$ & $0.470^{* *}$ \\
\hline
\end{tabular}

* and ${ }^{* *}$ significant at $P_{=} 0.05$ and $P_{=} 0.01$ level of significance respectively.

$D T=$ Days to tasseling, $D S=$ Days to silking, $T S I=$ Tasseling silking interval, $P H=P$ lant height $(\mathrm{cm}), E H=E a r$ height $(\mathrm{cm}), P / P=$ Number of harvested plants $/$ plot, $E / P=$ Number of harvested ears $/$ plot, $E L=$ Ear length $(\mathrm{cm}), E D=$ Ear diameter $(\mathrm{cm}), H C=H u s k$ cover rating in 1-5 scale, GY= Grain Yield $\mathrm{kg} / \mathrm{ha}$

Grain yield had shown significant positive association for plant height, number of harvested plants/plot, number of harvested ears/plot, ear length and ear diameter indicated that selection in favour of these traits will improve grain yield on early maturing maize 
genotypes. These findings were in conformity with previous reporting by (Bhusal et al., 2017; Ogunniyan and Olakaago, 2014; Khan et al., 2018; Sharma et al., 2018). In addition non significant correlation was observed for days to tasseling $(r=0.3)$, days to silking $(r=0.274)$, ear height $(r=0.158)$ and husk cover rating $(r=-0.264)$ with grain yield.

\section{Conclusions}

This study identified maize genotypes SO3TEY-PO-BM, COMPOL-NIOBP and ACROSS99402 suitable for rainfed bariland farming based on the maturity and yield performance. Dipal local was found extra early, thus it could be one of the parents for maize breeding program for developing early maturing maize varieties. This study indicated the genetic variability on the studied genotypes mostly inherited by non additive gene action and direct selection is not fruitful, so hybridization followed by selection is recommended for improvement. As plant height, number of harvested pods/plot, number of harvested ears/plot, ear length and ear diameter were found significantly positively correlated with maize grain yield thus selection applied in favour these traits will simultaneously improve maze yield of selected plants.

\section{Acknowledgments}

The authors would like to thank National Maize Research Program, Rampur for providing testing genotypes and technical support. We would like to thank technical officer Mr. MB Chodaro and technical assistant staffs of Regional Agricultural Research Station, Doti, Nepal for their support on conducting research activities.

\section{References}

Adhikari, B.N., Pokhrel, B.B. \& Shrestha, J. 2018. Evaluation and development of Fingermillet (Eleusine coracana L.) genotypes for cultivation in high hills of Nepal. Fmg. \& Mngmt., 3(1): 37-46.

Aditya, J.P. \& Bhartiya, A. 2013. Genetic variability, correlation and path analysis for quantitative characters in rainfed upland rice of Uttarakhand hills. Journal of Rice Research, 6(2): 24-34.

Allard, R.W. 1960. Principles of Plant Breeding. $1^{\text {st }}$ Edn., John Wiley and Sons Inc., New York.

Bhusal, T., Lal, G.M., Marker, S. \& Synrem, G.J. 2017. Genetic variability and traits association in maize (Zea mays L.) genotypes. Annals of Plants and Soil Research, 19(1): 59-65.

Bisen, N., Rahangdale, C.P. \& Sahu, R.P. 2018. Genetic variability and correlation studies of yield and yield component in maize hybrids (Zea mays L.) under Kymore Plateau and Satpura hill region of Madhya Pradesh. International Journal of Agriculture, Environment and Biotechnology, 11(1): 71-77. DOI: 10.30954/09741712.2018.00178.9

Carangal, V.R., Ali, S.M., Koble, A.F., Rinke, E.H. \& Sentz, J.C. 1971. Comparison of S1 with testcross evaluation for recurrent selection in maize. Crop Science, 11: 658-661.

Falconer, D.S. 1964. Introduction to Quantitative Genetics. Oliver and Boyd LTD, Welbeck Street, London.

Girma, B.T., Kitil, M.A., Banje, D.G., Biru, H.M. \& Serbessa, T.B. 2018. Genetic variability study of yield and yield related traits in rice (Oryza sativa L.) genotypes. Adv. Crop. Sci. Tech., 6 (4): 381. DOI:10.4172/2329-8863.1000381

Johnson, H.N., Robinson, H.F. \& Comstock, R.E. 1955. Estimate of genetic and environmental 
variability in Soybean. Agronomy Journal, 27: 314-318.

Kandel, M., Ghimire, S. K., Ojha, B. R. \& Shrestha, J. 2018. Correlation and path analysis for grain yield and its attributing traits of maize inbred lines (Zea mays L.) under heat stress condition. International Journal of Agriculture, Environment and Food Sciences, 2(4): 124-130.

Katuwal, R.B., Chaudhary, R.N., Yadav, J.K., Yadav, M., Yadav, D., Yadav, B. \& Niraula, B. 2017. Performance evaluation of early, full season and quality protein maize varieties in the eastern hills of Nepal. In: Giri Y.P, Mahato, B.N., Gautam, A.K., Khatiwoda, S.P., Shrestha, R., Joshi, B.K., Khatri, B.B., Rai, S.K., Ghimire, Y.N., Luitel, B.P., Upreti, H.K., Sah, K, Sharma, P.N., Bajracharya, A.S.R., Baidhya, S., Shrestha, J. \& Manandhar, S. (Eds). Proceedigs of the $28^{\text {th }}$ Summer Crops Workshop 17-18 March 2015, National Rice Research Program, Hardinath, Dhanusha, Nepal Agricultural Research Council, 284295.

Khan, M.H., Ahmad, M., Hussain,M. Hassan-ul, M. \& Ali, Q. 2108. Heritability and trait association studies in Maize F1 hybrids. International Journal of Biosciences, 12(1): 1826.

Khush, G.S. 2013. Strategies for increasing the yield potential of cereals: Case of rice as an example. Plant Breeding, 132: 433-436. DOI:10.1111/pbr.1991

Kothari, C.R. 2004. Research Methodology, Methods and Techniques. $2^{\text {nd }}$ Edn., New Age International Publishers, India.

MOAD. 2017. Statistical Information on Nepalese Agriculture 2072/73 (2015/16). Government of Nepal. Ministry of Agricultural Development. Monitoring, Evaluation and Statistics Division. Agri-Statistics Section Singhadurbar, Kathmandu Nepal.

Ogunniyan, D.J. \& Olakojo, S.A. 2014. Genetic variation, heritability, genetic advance and agronomic character association of yellow elite inbred lines of maize (Zea mays L.). Nigerian Journal of Genetics, 28: 24-28.

Pahadi, P. \& Sapkota, M. 2016. Variability, correlation and path coefficient analysis in maize (Zea mays L.) genotypes in Baitadi, Nepal. Int. J. Exp. Res. Rev., 6: 25-34.

Pal, S., Sharma, H.R., Rai, A.K. \& Bhardwaj, R.K. 2016. Genetic variability, heritability and genetic gain for yield and quality traits in Cucumber (Cucumis sativus L.) genotypes. The Bioscan, 11(3): 1985-1990.

Prasai, H.K., Kushwaha, U.K.S., Joshi, B.P., \& Shrestha, J. 2015. Performance evaluation of early maize genotypes in far western hills of Nepal. Journal of Maize Research and Development, 1(1): 106-111.

RARS. 2015. Annual Report 2071/72 (2014/15). Government of Nepal. Nepal Agricultural Research Council. Regional Agricultural Research Station (RARS). Bhagetada, Dipayal, Doti.

Sharma, B.K., Sharma, S., Kandel, B.P. \& Shrestha, J. 2018. Varietal evaluation of promising maize genotypes. Azarian J. Agric. 5(4): 120-124.

Shrestha, J. (2014). Morphological variation in maize inbred lines. International Journal of Environment, 3(2): 98-107.

Shrestha, J., Yadav, D.N., Amgain, L.P. \& Sharma, J. P. (2018). Effects of nitrogen and plant density on maize (Zea mays L.) phenology and grain yield. Current Agriculture Research Journal, 6(2): 175-182.

Shukla S., Bhargava, A., Chatterjee, A., Srivastava, A. \& Singh, S.P. 2006. Genotypic variability in vegetable Amaranth (Amaranthus tricolor L.) for foliage and its contributing traits over successive cuttings and years. Euphytica, 151: 103-110. DOI: 10.1007/s10681- 
006-9134-3

Sivasubramanian, S. \& Madhavamenon, P. 1973. Combing Ability in Rice. Madras Agricultural Journal, 60: 419-421.

Sumanth V., Suresh, B.G., Ram, B.J. \& Srujana, G. 2017. Estimation of Genetic Variability, Heritability and Genetic Advance for Grain Yield Components in Rice (Oryza sativa L.). Journal of Pharmacognosy and Phytochemistry, 6: 1437-1439.

Vashistha, A., Dixit, N. N., Dipika, Sharma, S. K. \& Marker, S. 2013. Studies on Heritability and Genetic Advance Estimates in Maize Genotypes. Bioscience Discovery, 4: 165-168. 